\title{
Synthesis, self-assembly and electrochemical behavior of disulphide derivatised mesoporphyrin on gold electrodes
}

\author{
Shichao XU $\mathrm{XU}^{1,2,3,4, \mathrm{a} *}$, Zhendong ZHAO ${ }^{1,2,3,4, \mathrm{~b}}$, Bingcheng $\mathrm{HU}^{5, \mathrm{c}}$
}

${ }^{1}$ Institute of Chemical Industry of Forest Products, Chinese Academy of Forestry, Nanjing 210094, P.R. China

${ }^{2}$ Key Lab. of Biomass Energy and Material, Jiangsu Province, Nanjing 210042, China

${ }^{3}$ National Engineering Lab. for Biomass Chemical Utilization, Nanjing 210042, China

${ }^{4}$ Key and Open Lab. on Forest Chemical Engineering, State Forestry Administration, Nanjing 210042, China

${ }^{5}$ School of Chemical Engineering, Nanjing University of Science and Technology, Nanjing, Jiangsu Province 210094, China

axsclhs@163.com, ${ }^{b} z d z h a 0 @ 189 . c n,{ }^{c h}$ hubingcheng210094@163.com

Keywords: Mesoporphyrin disulphide derivative; Self-assembly; Biomimetic electrocatalysis.

Abstract. Disulphide derivatised mesoporphyrin (DSDMP) and its cobalt complex Co(II)DSDMP were conveniently synthesized and successfully immobilized onto gold surface by monolayer self-assembly of disulfide. The modified electrode was characterized by Infrared Spectrometer (IR) and X-ray photoelectron spectroscopy (XPS) and confirmed electrochemically by cyclic voltammogram (CV) and differential pulse voltammogram (DPV). The characterization results supported the stable formation of Co(II)DSDMP monolayer with a surface coverage of $1.48 \times 10^{-10} \mathrm{~mol} / \mathrm{cm}^{-2}$.

\section{Introduction}

Electrochemical study of enzymes and enzyme catalyzed reactions can simulate the electronic transfer mechanisms and the metabolic processes of biological systems and provide a powerful means for the exploitation of electrocatalytic applications ${ }^{1,2}$. However, the transfer of electrons between the active center of enzymes and electrodes is very slow since the active center of enzymes was deeply buried in peptide chains. Furthermore, the adsorption of impurities to bare electrode surface even causes the metamorphism of proteins. The desire to overcome these disadvantages has led to an active area toward the design, construction and application of biomimetic molecular models modified substrate surfaces $^{3,4}$.

Metallo-porphyrins (MPs) is a kind of important $18 \pi$-conjugated organic molecules and have been extensively employed to mimic the active sites of enzymes such as hemoglobin, myoglobin, cytochrome and nitric oxide reductase in electrochemical study ${ }^{5 \sim 8}$. Thus, the preparation and application of suitable designed electrode surfaces of porphyrins have attracted considerable attention during the last several decades ${ }^{6,9}$. Since it was introduced by Sagiv, self-assembly monolayer (SAM) of porphyrin thiolates on gold has been used as an efficient method to prepare stable and oriented electrode surfaces of porphyrins with a controllable thickness and desirable function ${ }^{10,11}$. However, the direct immobilization of thiol terminated MPs might bring some disadvantages because the thiol can coordinate the central metal ion of MPs, which leads to the formation of multilayer and the block of the catalytic centre with reactors ${ }^{12,13}$.

Several strategies have been reported to overcome these disadvantages such as inserting metal ions into pre-assembled porphyrin monolayers, covalent attachment of MPs to dimercapto-alkanemodified gold electrodes and axial attachment of the MP to pyridinethiol pre-assembled SAMs ${ }^{14}$. Although these methods have their respective advantages, there also exist some different shortcomings, such as approach-complicated, electron transfer-sluggish or time-consuming. It has been reported by Abrantes and coworkers that the formation of disulphide as anchor group instead of thiols could reduce the coordination ability of substituents towards the metallic centre and allow the formation of 
metalloporphyrin SAM in only one step, which provides a convenient method to overcome these defects mentioned above ${ }^{13,15}$.

Metallo-mesoporphyrin IX derivatives (MMPDs) are often the preferred choice in MPs biomimic catalyzed investigations ${ }^{16 \sim 18}$. However, to the best of our knowledge, there were few reports concerning the electrocatalytic ability and electrocatalytic application of MMPDs because of the difficulties in the synthesis and stable modification of MMPDs on substrate surfaces. In this work, a convenient synthetic method was explored for the synthesis of mesoporphyrin IX. A novel cobalt mesoporphyrin derivative Co(II)DSDMP was synthesized (scheme 1) and successfully self- assembled onto gold electrodes as a biomimic model for electrocatalyzed application. Many techniques such as IR, XPS, CV and DPV are used for the characterization of the modified electrodes.

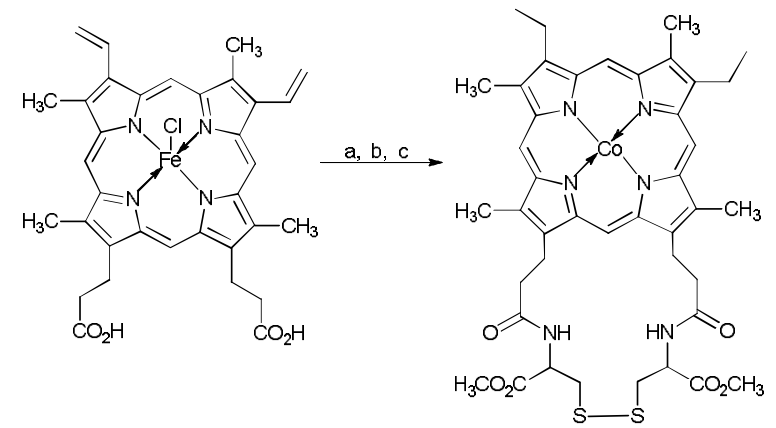

Scheme 1. Synthesis of Co(II)DSDMP. (a) $\mathrm{HCOOH}, \mathrm{Fe}$, reflux, $2 \mathrm{~h}$; (b) DMF, $\mathrm{Et}_{3} \mathrm{~N}, \mathrm{ClCOOC}_{2} \mathrm{H}_{5}$, L-Cys- $\mathrm{Me}_{2} \cdot 2 \mathrm{HCl}, \mathrm{rt}, 12 \mathrm{~h}$; (c) DMF, $\mathrm{CoCl}_{2} \cdot 6 \mathrm{H}_{2} \mathrm{O}$, reflux, $2 \mathrm{~h}$.

\section{Experimental}

\section{Chemicals}

All chemicals were of analytical grade obtained commercially and used without further purification. Organic solvents were dried before use. Double-distilled water was used throughout. Phosphatebuffered saline (PBS, $0.1 \mathrm{~mol} / \mathrm{L}^{-1}$ ) solutions were prepared by mixing stock solution of $\mathrm{NaH}_{2} \mathrm{PO}_{4}$ and $\mathrm{Na}_{2} \mathrm{HPO}_{4}$ and employed as supporting electrolyte. High purity nitrogen was purchased from Nanjing Special Gas Co., Ltd. (china) and used for deaeration. All supporting electrolyte and test solutions used in electrochemical experiments are deaerated before use if not demonstrated.

\section{Apparatus}

A Kofler hot-stagemicroscope (Kofler, USA) was used for the determination of melting points and used uncorrected. ${ }^{1} \mathrm{HNMR}$ spectra were obtained on a Bruker Avance III $500 \mathrm{MHz}$ spectrometer (Bruker, German) using DMSO- $\mathrm{D}_{6}$ as stated solvents, all chemical shifts were reference to tetramethylsilane (TMS) lock signal. For IR spectra, a Thermo Nicolte IS 10 IR instrument (Thermo, USA) was applied using attenuated total reflection method. ESI-MS results were recorded on a Finnigan TSQ Quantum ultra AM mass spectrometer (Finnigan, USA) with electrospray ionization (ESI) source. Elemental analysis was completed on a Perkin-Elmer PE-2400 elemental analyzer (Perkin- Elmer, USA). UV-vis spectra were recorded on a Lambda-35 UV-spectrofluorimeter (Perkin- Elmer, USA). The electrochemical experiments were performed on a $\mathrm{CHI} 842 \mathrm{C}$ electrochemical workstation (Chenhua Instrumental Co., China) using gold, Pt and SCE as working, counter and reference electrodes.

\section{Synthesis of DSDMP}

Mesoporphyrin was synthesized from hemin according to our previous work ${ }^{18}$. DSDMP was synthesized by the condensation of mesoporphyrin and cystine dimethyl ester dihydrochloride similar to our previous work ${ }^{19}$. Yield: $67.4 \%$. m. p. $>300{ }^{\circ} \mathrm{C} ;{ }^{1} \mathrm{H}$ NMR $\left(500 \mathrm{MHz}, \mathrm{DMSO}-\mathrm{d}_{6}\right), \delta / \mathrm{ppm}=: 10.31$ (s, 1H, 20-H), 10.20 (s, 1H, 15-H), 10.18 (s, 1H, 5-), 10.14 (s, 1H, 10-H), 8.82, 8.80 (2d, 2H, $J_{\mathrm{HH}}=7.8$ $\mathrm{Hz}, 13,17-\mathrm{NHCH}), 4.76(\mathrm{~m}, 2 \mathrm{H}, 13,17-\mathrm{NHCH}), 4.38,4.29\left(2 \mathrm{t}, 4 \mathrm{H}, J_{\mathrm{HH}}=7.5 \mathrm{~Hz}, 13-, 17-\beta-\mathrm{CH}_{2}\right.$, $\alpha$ to carbonyl), 4.11, $4.10\left(\mathrm{~m}, 4 \mathrm{H}, 3,8-\mathrm{CH}_{2} \mathrm{CH}_{3}\right), 3.65,3.64,3.63,3.62\left(4 \mathrm{~s}, 12 \mathrm{H}, 2-\right.$, 7-, 12-, 18- $\left.\mathrm{CH}_{3}\right), 3.45$, $3.42\left(2 \mathrm{~s}, 6 \mathrm{H}, 13,17-\mathrm{OCH}_{3}\right), 3.22,3.03\left(2 \mathrm{t}, 4 \mathrm{H}, J_{\mathrm{HH}}=7.5 \mathrm{~Hz}, 13-, 17-\alpha-\mathrm{CH}_{2}, \alpha\right.$ to carbonyl), 3.17 (m, $\left.4 \mathrm{H}, 13,17-\mathrm{NHCHCH}_{2}\right), 1.82,1.81\left(2 \mathrm{t}, 6 \mathrm{H}, \mathrm{J}_{\mathrm{HH}}=7.5 \mathrm{~Hz}, 3,8-\mathrm{CH}_{2} \mathrm{CH}_{3}\right),-4.01(\mathrm{~s}, 2 \mathrm{H}, \mathrm{NH}) ; \mathrm{IR}\left(\mathrm{cm}^{-1}\right)$ : 
$3300\left(\mathrm{~s}, v_{\mathrm{N}-\mathrm{H}}\right), 2926,2850\left(\mathrm{~m}, v_{\mathrm{C}-\mathrm{H}}\right), 1735\left(\mathrm{~s}, v_{\mathrm{C}=\mathrm{O}}\right), 1653\left(\mathrm{~s}, \delta_{\mathrm{N}-\mathrm{H}}\right), 1446\left(\mathrm{~m}, \delta_{\mathrm{CH} 2}\right), 1340\left(\mathrm{~m}, \delta_{\mathrm{CH} 3}\right), 1268$ (m), $1227\left(\mathrm{w}, v_{\mathrm{C}-\mathrm{O}}\right), 1022(\mathrm{~s}), 845(\mathrm{~m}), 711(\mathrm{~s}) ; \mathrm{ESI}^{+}-\mathrm{MS}(35 \mathrm{eV}), \mathrm{m} / \mathrm{z}: 798.93[\mathrm{M}+\mathrm{H}]^{+}, 752.48$ $\left[\mathrm{M}-\mathrm{H}_{3} \mathrm{COO}+\mathrm{H}\right]^{+}, \quad 733.10 \quad[\mathrm{M}-2 \mathrm{SH}+\mathrm{H}]^{+}, \quad 674.88 \quad\left[\mathrm{M}-2 \mathrm{SH}-2 \mathrm{CH}_{2} \mathrm{CH}_{3}+\mathrm{H}\right]^{+}$. Anal. Calcd for $\mathrm{C}_{42} \mathrm{H}_{50} \mathrm{~N}_{6} \mathrm{O}_{6} \mathrm{~S}_{2}$ : C 63.13, H 6.31, N 10.52; Found: C 63.41, H 6.18, N 10.67\%.

\section{Synthesis of Co(II)DSDMP}

$\operatorname{DSDMP}(0.25 \mathrm{~g}, 0.31 \mathrm{mmol})$ and $\mathrm{CoCl}_{2} \cdot 6 \mathrm{H}_{2} \mathrm{O}(0.26 \mathrm{~g}, 1.09 \mathrm{mmol})$ were added into DMF $(50 \mathrm{~mL})$ in a $150 \mathrm{~mL} 3$-neck-flask. The resulted reaction mixture was heated to $130{ }^{\circ} \mathrm{C}$ for $2 \mathrm{~h}$ and then cooled to room temperature. The mixture was added to water to crystal the products. The precipitates were filtrated and washed with water and recrystalled by dichloromethane. Yield: $86.8 \%$. m. p. $>300{ }^{\circ} \mathrm{C} ;{ }^{1} \mathrm{H}$ $\operatorname{NMR}\left(500 \mathrm{MHz}, \mathrm{CDCl}_{3}\right)$ : paramagnetic; IR $\left(\mathrm{cm}^{-1}\right)$ : $3294\left(\mathrm{~s}, v_{\mathrm{N}-\mathrm{H}}\right), 2922(\mathrm{~m}), 2859\left(\mathrm{~m}, v_{\mathrm{C}-\mathrm{H}}\right), 1716(\mathrm{~s}$, $\left.v_{\mathrm{C}=\mathrm{O}}\right), 1644\left(\mathrm{~s}, \delta_{\mathrm{N}-\mathrm{H}}\right), 1552(\mathrm{~m}), 1444\left(\mathrm{w}, \delta_{\mathrm{CH} 2}\right), 1244(\mathrm{~m}), 1092\left(\mathrm{~s}, v_{\mathrm{C}-\mathrm{O}}\right), 1017(\mathrm{~s}), 793(\mathrm{~m}), 709(\mathrm{w})$; ESI $^{+}$-MS $(35 \mathrm{eV}), \mathrm{m} / \mathrm{z}: 854.78[\mathrm{M}+\mathrm{H}]^{+}, 788.69[\mathrm{M}-2 \mathrm{SH}+\mathrm{H}]^{+}$; Anal. Calcd for $\mathrm{CoC}_{42} \mathrm{H}_{50} \mathrm{~N}_{6} \mathrm{O}_{6} \mathrm{~S}_{2}: \mathrm{C}$ 58.80, H 5.87, N 9.80; Found: C 58.49, H 6.03, N 9.96\%.

\section{Preparation of modified electrodes}

The gold electrodes ( $3 \mathrm{~mm}$ diameter) were successively polished to a mirror finish with 0.3 and 0.05 $\mu \mathrm{m}$ alumina slurry on chamois leather and then immersed for $3 \mathrm{~min}$ in a hot "pirhana" solution (3:1 mixture of concentrated $\mathrm{H}_{2} \mathrm{SO}_{4}$ and $30 \% \mathrm{H}_{2} \mathrm{O}_{2}$ ). After copious rinsing with water, the gold electrodes were electrochemically cleaned in $0.5 \mathrm{~mol} \mathrm{~L}^{-1} \mathrm{H}_{2} \mathrm{SO}_{4}$ in the potential range of $-0.2 \sim 1.6 \mathrm{~V}$ versus $\mathrm{Ag} / \mathrm{AgCl}$ at a scan rate of $20 \mathrm{mV} \mathrm{s}^{-1}$ until typical cyclic voltammogram of clean gold was obtained. The electrodes were rinsed with water, ethanol and chloroform and dried with nitrogen $(99.999 \%)$ at room temperature. The freshly prepared Co(II)DSDMP was dissolved in ethanol $\left(1 \mathrm{mmol} \mathrm{L}^{-1}\right)$ and protected from light to prevent photodecomposition and oxidation of the porphyrins. The polished electrodes were immersed in ethanolic solution of Co(II)DSDMP under nitrogen atmosphere for $48 \mathrm{~h}$ at $4{ }^{\circ} \mathrm{C}$. After assembly, the electrodes were rinsed with copious amount of ethanol and water, dried with nitrogen and used immediately for electrochemical measurements. The modified electrodes were washed with water and stored in a phosphate buffered solution at $4{ }^{\circ} \mathrm{C}$ when not in use.

\section{Results and discussion}

\section{Characterization of Co(II)DSDMP SAM}

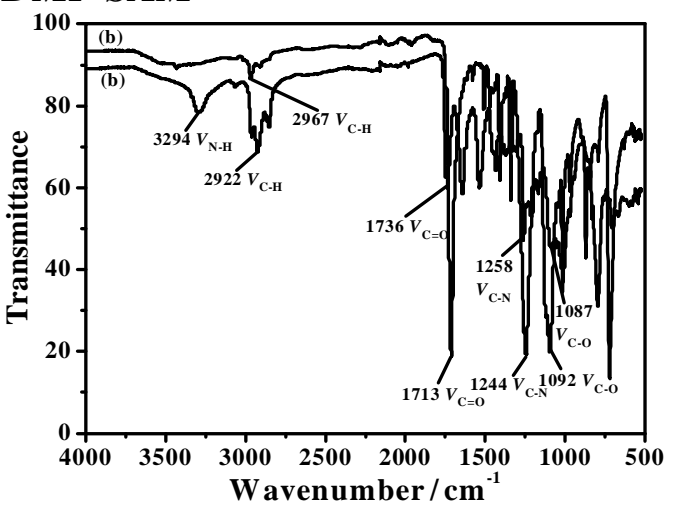

Figure 1. IR spectra of Co(II)DSDMP (a) and Co(II)DSDMP modified gold electrode (b).

The Co(II)DSDMP SAM was formed using the complex of disulfide group to Au on electrode surface. Infrared spectroscopy was used as a convenient method (usually in reflection-absorption mode) to identify the functional groups of the SAM adsorbed onto gold surfaces, using thick Au film to obtain effective reflection. Figure 1 depicts the IR spectra of Co(II)DSDMP and Co(II)DSDMP modified gold electrode. Figure 1 shows that the Co(II)DSDMP modified gold electrode (Figure 1, a) has characteristic antisymmetric stretching modes of $\mathrm{CH}_{2}$ at $2967 \mathrm{~cm}^{-1}$, overlapping stretching vibrations peak of acylamide and ester $\mathrm{C}=\mathrm{O}$ at $1736 \mathrm{~cm}^{-1}$ and stretching vibrations bond of $\mathrm{C}-\mathrm{N}$ and $\mathrm{C}-\mathrm{O}$ at 1258 and $1087 \mathrm{~cm}^{-1}$, coinciding with the bulk IR spectrum of Co(II)DSDMP (Figure 1, b). It can be also found from Figure 2 that the stretching vibration peak of N-H at $3294 \mathrm{~cm}^{-1}$ disappears after assembly, 
which is the indication of the chemical adsorption of $\mathrm{NH}$ on gold surface. These results clearly indicate the adsorption of Co(II)DSDMP on gold surface.

\section{Electrochemical behavior of Co(II)DSDMP SAM}

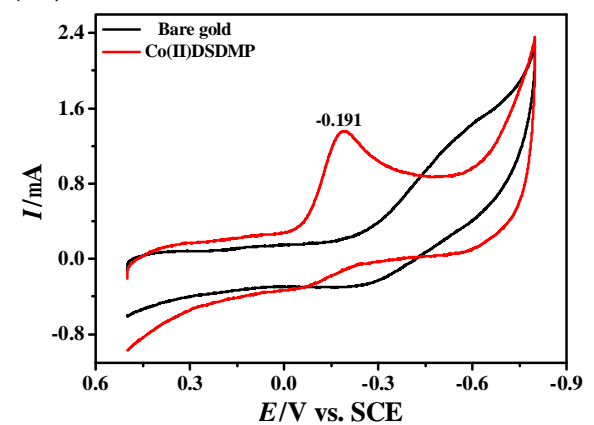

Figure 2. CVs of bare gold electrode and Co(II)DSDMP modified gold electrode in $0.1 \mathrm{~mol} \mathrm{~L}^{-1}$ $\mathrm{N}_{2}$-saturated $\mathrm{pH} 7.0 \mathrm{PBS}$ with a scan rate of $0.1 \mathrm{~V} \mathrm{~s}^{-1}$.

The CV of gold electrode in $0.2 \mathrm{~mol} \mathrm{~L}^{-1} \mathrm{PBS}$ did not show an observable peak in the potential range of $0.5 \mathrm{~V}$ to $-0.8 \mathrm{~V}$ (Figure 2, black line) at sweep rate of $0.1 \mathrm{v} \mathrm{s}^{-1}$, whereas the modified electrode showed a formal potential of $\mathrm{Co}(\mathrm{III}) / \mathrm{Co}$ (II) at $-0.191 \mathrm{~V}$ (Figure 2, red line), which was attributed to the formation of monolayer via disulphide to gold electrode. The reduction wave is irreversible and ill-defined presumably due to the slow heterogeneous electron transfer rate. Compared with cystine dimethyl ester derivated deuteroporphyrins Co(II)TPMP we have synthesized before ${ }^{19}$, the reductive peak is less negative with higher current, which implied that Co(II)DSDMP has higher electrocatalytic activity than Co(II)TPMP and the structure of porphyrin was an important factor in the electron transfer process.

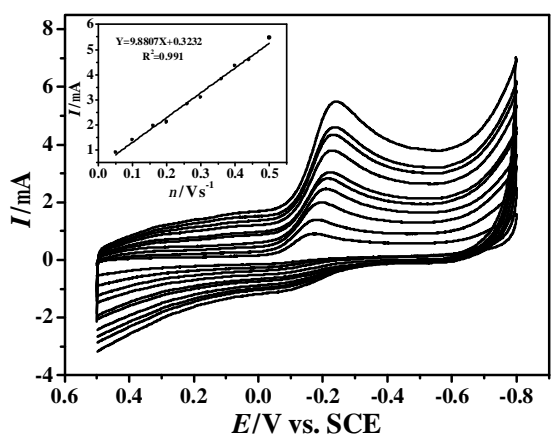

Figure 3. CVs of Co(II)DSDMP modified gold electrode in $0.1 \mathrm{~mol} \mathrm{~L}^{-1} \mathrm{~N}_{2}$-saturated $\mathrm{pH} 7.0 \mathrm{PBS}$ at different scan rates $\left(0.05,0.1,0.16,0.2,0.26,0.3,0.36,0.4,0.44\right.$, and $\left.0.5 \mathrm{~V} \mathrm{~s}^{-1}\right)$.

Figure 3 shows the CVs of the modified electrode at different scan rates in the potential range from $0.5 \mathrm{~V}$ to $-0.8 \mathrm{~V}$. As can be seen in Figure 3, the reduction peak potential shifts negatively when the scan rate increases and the reduction peak currents of Co(II)DSDMP modified gold electrode increases linearly as the scan rate increased from 0.05 to $0.5 \mathrm{mV} \mathrm{s}^{-1}$, suggesting a adsorptioncontrolled electrode process. In addition, corresponding fitting lines for relationship between potential and scan rate $v$ can be obtained as $\mathrm{E}_{\mathrm{p}}(\mathrm{V})=-0.155-2.94 \times 10^{-4} v(\mathrm{mV} / \mathrm{s}), \quad \mathrm{r}=0.989 ; \quad \mathrm{E}_{\mathrm{p}}(\mathrm{V})=$ $-0.0399-0.0372 \operatorname{lnv}, r=0.994$. For an adsorption controlled totally irreversible electrode process, the relationship between $\mathrm{E}_{\mathrm{P}}$ and $v$ can be expressed by the Laviron's equation ${ }^{20}$ :

$$
E_{\mathrm{p}}=E^{0}+\left(\frac{\mathrm{RT}}{\alpha \mathrm{nF}}\right)\left[\ln \left(\frac{\mathrm{RTk}_{\mathrm{s}}}{\alpha \mathrm{nF}}\right)-\ln v\right]
$$

where $\mathrm{E}^{0}, \mathrm{R}, \mathrm{T}, \alpha, \mathrm{n}, \mathrm{k}_{\mathrm{s}}$ and $\mathrm{F}$ are the formal potential, the universal gas constant $\left(8.314 \mathrm{~J} \mathrm{~K}^{-1} \mathrm{~mol}^{-1}\right)$, the Kelvin temperature, the transfer coefficient, the number of reaction electrons, the electrochemical rate constant and Faraday constant $\left(96487 \mathrm{C} \mathrm{mol}^{-1}\right)$. The value of $\mathrm{E}^{0}$ was obtained by the extrapolation of $\mathrm{E}_{\mathrm{P}}-v$ equation to the vertical axis at $v=0.00\left(\mathrm{~V} \mathrm{~s}^{-1}\right)^{21}$. The values of the an and $\mathrm{k}_{\mathrm{s}}$ could be easily calculated from the slope and intercept of $\mathrm{E}_{\mathrm{P}}-\ln v$ equation. Thus, $\mathrm{E}^{0}, \mathrm{a}, \mathrm{n}$ and $\mathrm{k}_{\mathrm{s}}$ were calculated to be $-0.175 \mathrm{~V}, 0.69,1$ and $4.018 \pm 0.36 \mathrm{~s}^{-1}$, respectively. The surface coverage $\Gamma$ of substances could be obtained from the relationship between $\mathrm{I}_{\mathrm{P}}$ and $v$ with the following formula ${ }^{22}$ : 


$$
I_{\mathrm{p}}=\frac{\mathrm{n}^{2} \mathrm{~F}^{2} v \mathrm{~A} \Gamma}{4 \mathrm{RT}}
$$

where $\mathrm{A}$ is the geometric area of electrode, and the other symbols have their usual meanings. In the present study, the effective surface area of bare gold electrode was $0.071 \mathrm{~cm}^{2}$. Thus, the surface coverage $\Gamma$ was calculated to be $1.48 \times 10^{-10} \mathrm{~mol} / \mathrm{cm}^{-2}$, slightly smaller than the normal value of alkane based SAMs, which might attributed to the bigger molecule size of porphyrin derivatives.

\section{Conclusion}

A novel disulphide modified mesoporphyrin Co(II)DSDMP was synthesized and stably self- assembled onto gold electrodes. The monolayer formation was characterized by IR, XPS and confirmed by CV and DPV. The surface coverage of modified electrode, obtained from the charge under a desorption wave, was $1.48 \times 10^{-10} \mathrm{~mol} \mathrm{~cm}$. It is expected that this approach will be a convenient way for the elaboration of biomimetic SAMs based on cobalt-mesoporphyrins.

\section{Acknowledgements}

This work was supported by National Nonprofit Institute Research Grant of CAFYBB (Grant No. CAFYBB2014QA022).

\section{References}

[1] R.K. Shervedani, A. Amini, Bioelectrochem. 84 (2012) 25-31.

[2] M. Zhang, S. Karra, W. Gorski, Anal. Chem. 85 (2013) 6026-6032.

[3] J. Tang, D.P. Tang, B.L. Su, J.X. Huang, B. Qiu, G.N. Chen, Biosens. Bioelectron. 26 (2011) 3219-3226.

[4] T.F. Otero, M. Alfaro, V. Martinez, M.A. Perez, J.G. Martinez, Adv. Funct. Mater. 23 (2013) 3929-3940.

[5] L.N. Wu, J.P. Lei, X.J. Zhang, H.X. Ju, Biosens. Bioelectron. 24 (2008) 644-649.

[6] I. Beletskaya, V.S. Tyurin, A.Y. Tsivadze, R. Guilard, C. Stern, Chem. Rev. 109 (2009) 16591713 .

[7] J. Heinecke, P.C. Ford, Coord. Chem. Rev., 254 (2010) 235-247.

[8] S.C. Xu, W.W. Liu, B.C. Hu, W. Cao, Z.L. Liu, J. Photochem. Photobiol., A 227 (2012) 32-37.

[9] S. Chaiyasith, T. Tangkuaram, P. Chaiyasith, J. Electroanal. Chem. 581 (2005) 104-110.

[10] S. Yamada, T. Tasaki, T. Akiyama, N. Terasaki, S. Nitahara, Thin Solid Films, 438-439 (2003) 70-74.

[11] W.T. Wang, X.J. Li, X.Y. Wang, H. Shang, X.H. Liu, X.Q. Lu, J. Phys. Chem. B 114 (2010) 10436-10441.

[12]H. Imahori, H. Norieda, Y. Nishimura, I. Yamazaki, K. Higuchi, N. Kato, T. Motohiro, H. Yamada, K. Tamaki, M. Arimura, Y. Sakata, J. Phys. Chem. B 104 (2000) 1253-1260.

[13]A.S. Viana, S. Leupold, F.P. Montforts, L.M. Abrantes, Electrochim. Acta 50 (2005) 28072813.

[14]G.F. Zuo, H.Q. Yuan, J.D. Yang, R.X. Zuo, X.Q. Lu, J. Mol. Catal. A: Chem. 269 (2007) 46-52.

[15] C.M. Cordas, A.S. Viana, S. Leupold, F.P. Montforts, L.M. Abrantes, Electrochem. Commun. 5 (2003) 36-41.

[16]F.A. Lara, U. Lins, G.H. Bechara, P.L. Oliveira, J. Exp. Biol. 208 (2005) 3093-3101.

[17]J.S. Rebouças, B.R James, Tetrahedron Lett. 47 (2006) 5119-5122.

[18]Q.L. Cui, S.C. Xu, C.G. Sun, B.C. Hu, Chem. J. Chinese U. 32 (2010) 2311-2315.

[19] S.C. Xu, B.C. Hu, W.Y. Zhou, C.G. Sun, Z.L. Liu, Chin. Chem. Lett. 23 (2012) 157-160.

[20]E. Laviron, J. Electroanal. Chem. 52 (1974) 395-402. 
[21] Y.H. Wu, X.B. Ji, S.S. Hu, Bioelectrochem. 64 (2004) 91-97.

[22] Y.X. Dai, N. Zhang, D. Wu, J. Yang, J. Zhao, G.D. Chen, W. Zhao, R. Feng, B. Du, Q. Wei, J. Inorg. Organomet. Polym., 21 (2011) 871-875. 